\title{
Lasers in orthodontics
}

\author{
Rajiv Ahluwalia ${ }^{1, *}$, Shabih Fatima ${ }^{2}$, Shruveta Srivastava ${ }^{3}$, Parvinder Kaur ${ }^{4}$ \\ ${ }^{1}$ Professor and HOD, ${ }^{2,3}$ Post Graduate Student, ${ }^{4}$ Reader, Dept. of Orthodontics and Dentofacial Orthopedics, Santosh Dental \\ College and Hospital, Ghaziabad, Uttar Pradesh, India
}

*Corresponding Author:

Email: drrajivahluwalia@gmail.com

\begin{abstract}
Dentistry, in all its neoteric era revolves around the techniques and procedures that are advantageous and patient friendly. Such a research led to the institution of light amplification and stimulated emission of radiation technique, both in medicine and dentistry. Lasers are currently being followed in all the specialties including orthodontics, wherein it has dramatically decreased the treatment timings, resulting in better outcomes along with pain reduction procedures, greater patient satisfaction and a superior practice.
\end{abstract}

Keywords: Light amplification and stimulated emission of radiation (LASER), Orthodontics, Dentistry, LLLT, Accelerated tooth movement, Crown lengthening, Micro-etching of enamel.

\section{Introduction}

Lasers are finding their way into today's top orthodontic practices, aiding the doctors in managing usual soft tissue problems associated with patients in braces. Launching this technology safely and successfully depends largely on the doctor's commitment to doing it right. It is important to engage in training and developing systems for incorporating procedures into practice. Integrating these steps, greatly facilitates laser implementation and advances the orthodontist's expertise, confidence, and satisfaction.

History of the Laser: "LASER," an acronym for light amplification for stimulated emission of radiation, is a device for generating high intensity, evidently parallel beam of monochromatic electromagnetic radiation. The probability of stimulated emission was anticipated by Einstein in 1917.

Theodore Maiman ${ }^{1}$ created a first operational laser in 1960, based on the work of Gordon in 1955 and Schawlow and Townes in 1958. A ruby laser emitting a brilliant red beam of light was constructed. Development of argon, carbon dioxide, and neodymium: yttriumaluminium-garnet $(\mathrm{Nd}: \mathrm{YAG})^{2,3}$ lasers within 3 years from the construction of ruby laser occurred. These remain the most widely used lasers in dentistry and medicine till date. Soft lasers, which are based on the semiconductor diode devices, are compact, low-cost devices being used predominantly, are termed as lowlevel laser therapy (LLLT) or 'biostimulation'. ${ }^{4}$ The probability of stimulated emission was anticipated by Einstein in 1917.5

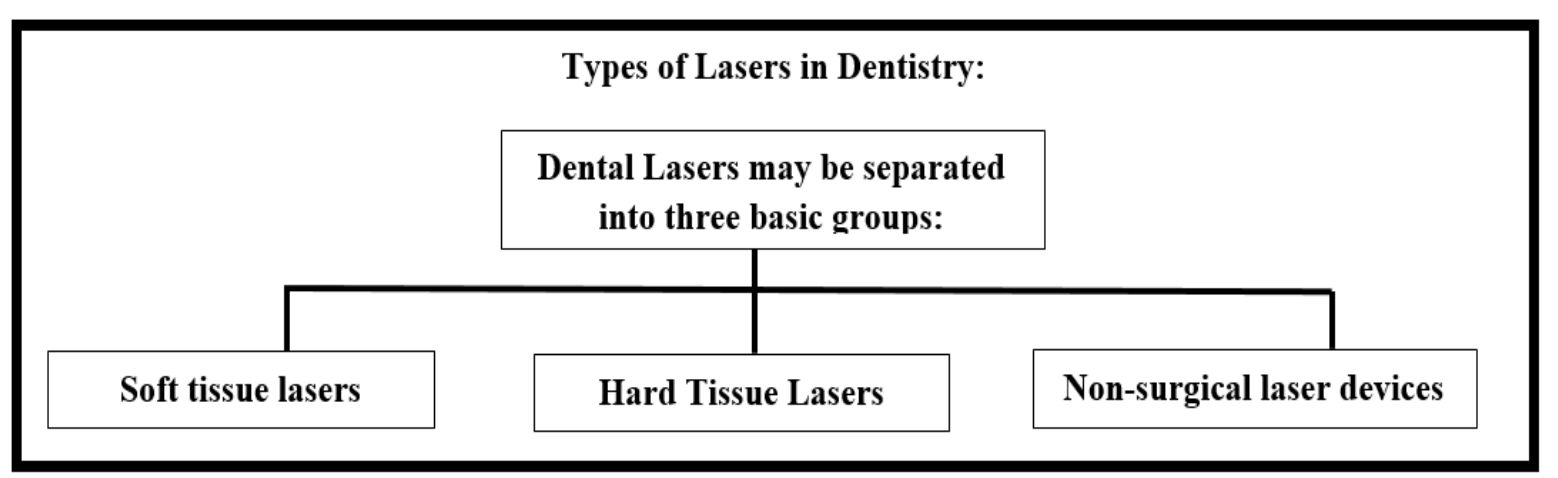

Fig. 1: Flowchart depicting types of lasers used in dentistry

Types of Lasers: There are about four types of lasers being used in dentistry today.

Erbium Laser: This laser can be used on hard tissue ${ }^{6}$ for cavity preparation or bone cutting, using short pulses of 50-100 microseconds. It can also be used on soft tissue, using longer pulses of 300-1000 microseconds. In this mode it can be used for periodontal procedures, gingival contouring, frenectomies, facial resurfacing or biopsies. The benefits of using this type of laser include minimal heat penetration, ${ }^{7}$ rapid healing and minimal postoperative pain. However, these lasers are large and expensive and have significantly more capability than an orthodontist generally would use in everyday cases. 


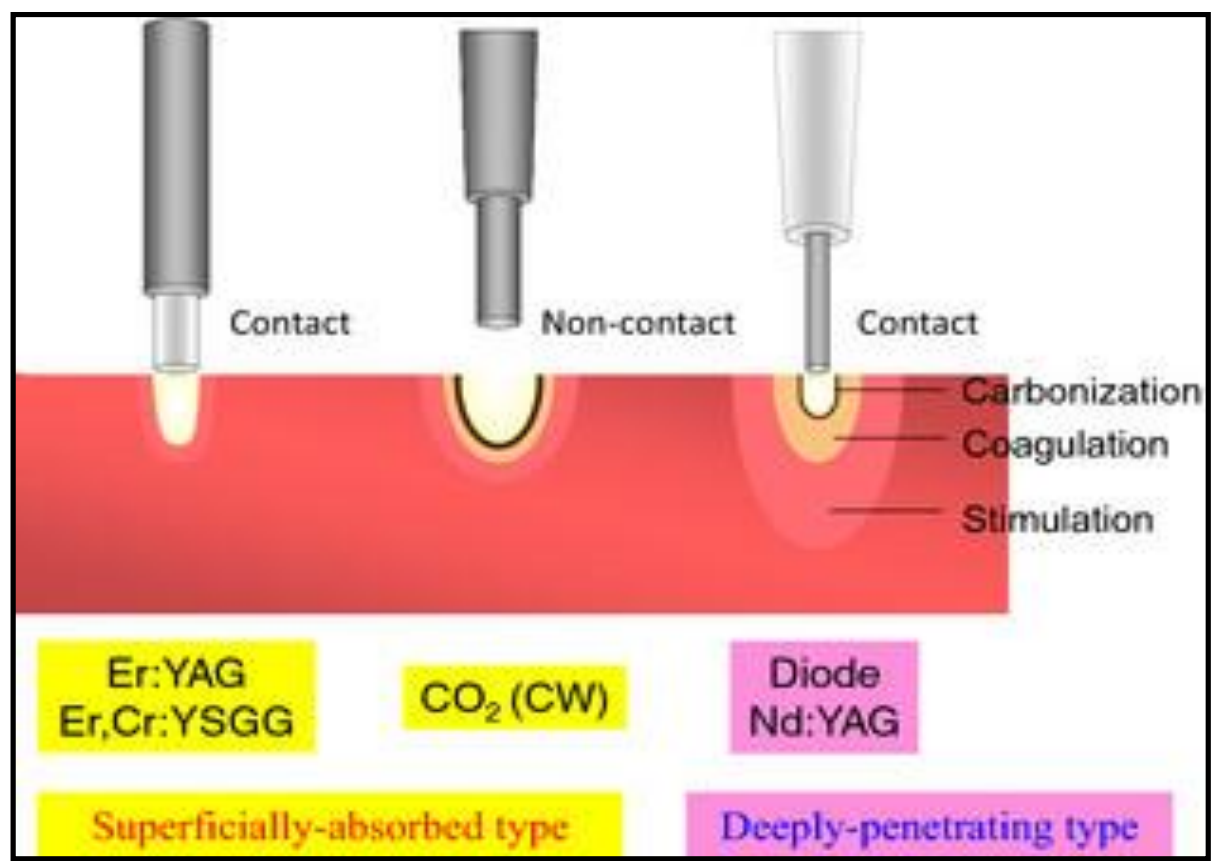

Fig. 2: Tissue penetration of different types of laser Image source: (http://www.mdpi.com/2076-3417/5/4/1350)

Nd:YAG Laser: This was the first laser designed for dentists, and was introduced in 1990. A pulse laser with a wavelength of $1064 \mathrm{~nm}$, the Nd:YAG laser has the unique ability to penetrate deep into the tissue,${ }^{8}$ and can even stimulate fibrin formation, aiding in the coagulation of operative sites. This laser has been used in the periodontal field ${ }^{9}$ for disinfection and debridement of periodontal pockets and the Laser Assisted New Attachment Procedure (LANAP). ${ }^{10}$

CO2 Laser: Introduced in the 1970s, this laser has a wavelength of $1060 \mathrm{~nm}$ and is highly absorbed by ${ }^{11}$ water. It is very good at hemostasis but can be used on soft tissue only. It is useful for cutting soft tissue with reduced charring, and is used most frequently for biopsies. Sutures are seldom needed since hemostasis is exceptionally good.

Diode Laser: Compact and affordable, this laser is used most frequently by orthodontists for soft-tissue management. The diode laser's wavelengths range from $805-1064 \mathrm{~nm}$, which means it can only be used on soft tissue. A wavelength of $940 \mathrm{~nm}$ represents peaks for the absorption of laser energy by hemoglobin, oxyhemoglobin and water, making the $940 \mathrm{~nm}$ diode laser very effective as an instrument to incise gingival tissue.

A diode laser uses heat as the energy source to incise the tissue, and it can be used quite effectively for frenectomies and photostimulation of the apthous and herpetic lesions. ${ }^{12}$ It is also utilized in doing biopsies, canine exposure, gingival recontouring and gingivectomies. Minor charring is very common around the surgical site, but resolves within a three- to five-day window under normal circumstances. The light energy produced by a laser can have four different interactions with a target tissue..$^{13,14}$ Reflection, transmission, scattering, and absorption.

Table 1: Comparisons of lasers used in dentistry

\begin{tabular}{|c|c|c|c|c|}
\hline S. No. & Laser Type & Wavelength & Tissues & Examples \\
\hline 1 & Diode & $800-900 \mathrm{~nm}$ & Soft and Hard & $\begin{array}{ll}\text { 1. } & \text { Soft tissue crown Lengthening } \\
\text { 2. } & \text { Tissue removal from orthodontic } \\
& \text { brackets } \\
\text { 3. } & \text { Frenectomy } \\
\text { 4. } & \text { Excisional biopsy } \\
\text { 5. } & \text { Tooth whitening } \\
\text { 6. } & \text { Caries detection } \\
\text { 7. } & \text { Desensitization } \\
\text { 8. } & \text { Treat temporomandibular joint } \\
& \text { disorder }\end{array}$ \\
\hline 2 & Nd: YAG & $1064 \mathrm{~nm}$ & Hard & 1. Tissue retraction \\
\hline
\end{tabular}




\begin{tabular}{|c|c|c|c|c|}
\hline & & & & 2. $\quad$ Biopsies \\
\hline 3 & Er: YAG & $2940 \mathrm{~nm}$ & Soft & $\begin{array}{ll}\text { 1. } & \text { Cavity Preparation } \\
\text { 2. } & \text { Endodontic procedures } \\
\text { 3. } & \text { Calculus removal } \\
\text { 4. } & \text { Sealant preparation }\end{array}$ \\
\hline 4 & Er Cr: YSGG & $2780 \mathrm{~nm}$ & Hard and Soft & $\begin{array}{ll}\text { 1. } & \text { Root debridement and scaling } \\
\text { 2. } & \text { Cavity preparation } \\
\text { 3. } & \text { Lesion removal } \\
\text { 4. } & \text { Excisional biopsy } \\
\text { 5. } & \text { Aphthous ulcer treatment } \\
\end{array}$ \\
\hline 5 & $\mathrm{CO}_{2}$ & $1060 \mathrm{~nm}$ & Soft & $\begin{array}{ll}\text { 1. } & \text { Frenectomy } \\
\text { 2. } & \text { Biopsy } \\
\text { 3. } & \text { Gingivectomy } \\
\text { 4. } & \text { Gingivoplasty } \\
\end{array}$ \\
\hline 6 & Argon & $514 \mathrm{~nm}$ & Soft & $\begin{array}{ll}\text { 1. } & \text { Curing } \\
\text { 2. } & \text { Whitening } \\
\text { 3. } & \text { Coagulation } \\
\text { 4. } & \text { Transillumination } \\
\end{array}$ \\
\hline
\end{tabular}

Steps to incorporate laser into practice:

I: Invest in a good dental diode laser system suitable to your needs and budget

The factors to be taken into consideration are:

1. Need

2. Wavelength

3. Pulse characteristics

4. Maximum wattage

5. Budget

II: Laser implementation into practice

1. Ensure Maximum Safety with personal protective equipment (safety glasses for the doctor staff as well as the patient)

2. Adequate training of the doctor and the staff
3. Treatment area modifications

4. Minimize reflective surfaces

5. Ensure manufacturer safeguards are in place

6. Use high volume suction

7. Follow normal infection control protocols

8. Designate a staff member as laser safety in charge.

III: Obtaining patients detailed history and informed consent

IV: Planning

1. Laser mode selection for different procedures

2. Doctor must know their limitations and schedule accordingly

3. Anesthesia levels to be planned according to the patient.

Dental laser wavelength on electromagnetic spectrum

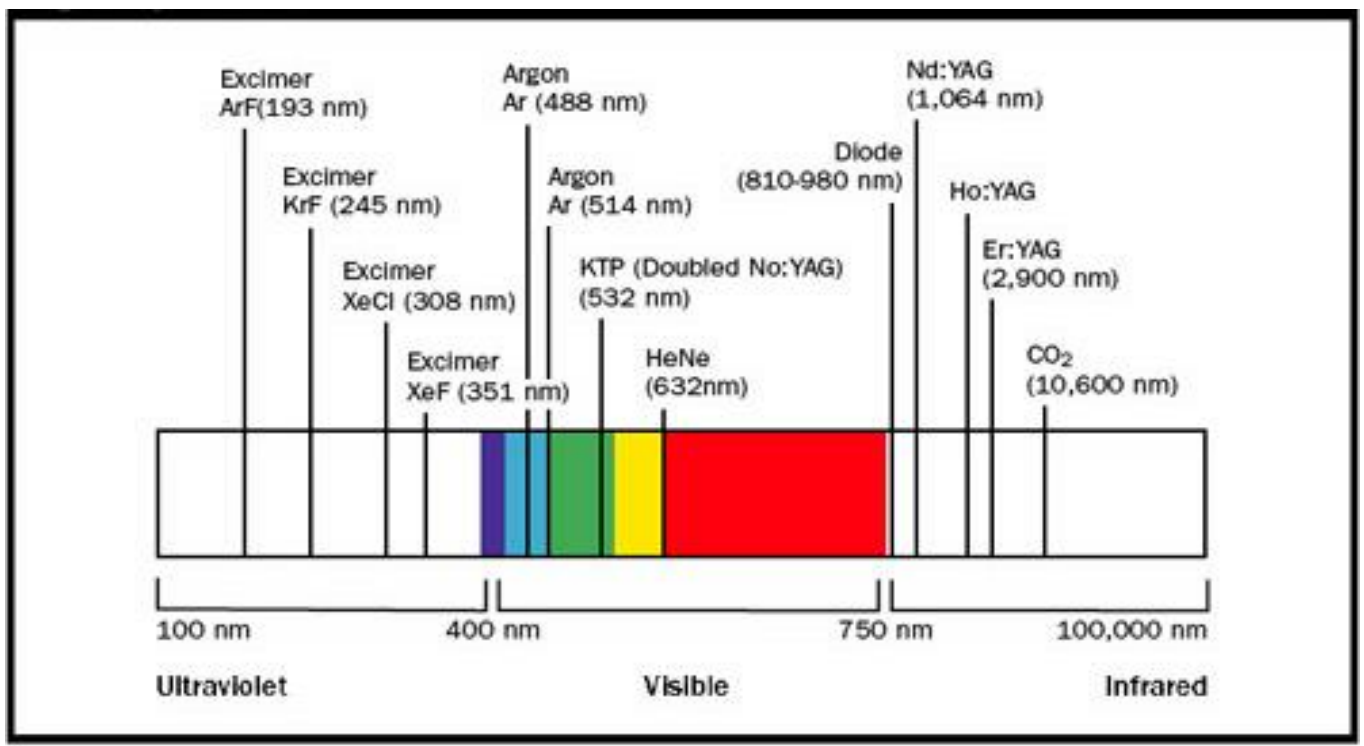

Fig. 3: Tissue penetration of different types of laser

Image source: (https://www.dentalcetoday.com/courses/28/HTML/dt_section_1.htm) 
Orthodontic Clinical Applications: Specific procedures include aesthetic gingival recontouring, soft tissue crown lengthening, exposure of impacted teeth, removal of inflamed and hypertrophic tissue, healing of wound $^{16}$ and frenectomies. Incorporating the use of lasers into orthodontic practice has been extremely productive on many levels. Placement of brackets more accurately and healing of exposed impacted teeth has significantly reduced treatment time and patients appreciate, the reduction of surgical complications and appreciate the way their smile has improved in a much lesser time.

1. Exposure of un-erupted and partially erupted teeth (reduced bleeding and swelling, improved precision, reduced pain and improved healing).

2. Isolated areas of transient tissue hypertrophy can easily be removed with the diode laser. ${ }^{17}$

3. Gingivectomy, gingivoplasty; gingival recontouring and esthetic crown lengthening. ${ }^{18,19}$

4. Frenectomies; A laser permits painless excision of frenum, without bleeding, sutures, surgical packing, or special postoperative care. ${ }^{20}$

5. Accelerate orthodontic tooth movement

6. Temporomandibular disorders pain management therapy. ${ }^{21-23}$

7. Pain control with Low level laser therapy (LLLT) or 'biostimulation'. 4,24-27

8. Enamel etching 28,29

9. Bonding

10. Bracket debonding

11. Homeostasis

12. Newer brackets with bracket base being cut by the laser technology.

13. Wound healing and treatment of traumatic and aphthous ulcers. ${ }^{16}$

14. Treatment of Post herpetic neuralgia. ${ }^{17,}$ 20, 30-32

15. Holographic studies. ${ }^{33-35}$

\section{Conclusion}

Laser treatment enhances patient experience and saves considerable time.

The patient experience is very positive and in most cases only a topical anaesthetic is used and generally most patients report that they did not need to take any analgesics following the procedures. Incorporating laser technology could significantly benefit any orthodontic practice as an aid for adjunct procedures.

\section{References}

1. Maiman TH. Stimulated optical radiation in ruby lasers. Nature 1960;187:493.

2. Walsh LJ. Dental lasers: Some basic principles. Postgrad Dent 1994;4:26-9.

3. Pick RM, Miserendino LJ. Chicago: Quintessence. Lasers in dentistry 1995;17-25.

4. Goldman L, Goldman B, Van-Lieu N. Current laser dentistry. Lasers Surg Med 1987;6:559-62.

5. Einstein A. Zur Quantentheorie der Strahlung. Physiol Z 1917;18:121-8.
6. Harashima T, Kinoshita J, Kimura Y, Brugnera A, Zanin F, Pecora JD, et al. Morphological comparative study on ablation of dental hard tissue at cavity preparation by Er: YAG and Er, CR: YSGG lasers. Photomed Laser Surg. 2005;23:52-5.

7. Ishikawa I, Aoki A, Takasaki AA. Clinical application of erbium: YAG Laser in periodontology. J Int Acad Periodontol 2008;10:22-30.

8. Fornaini C, Rocca JP, Bertrand MF, Merigo E, Nammour $\mathrm{S}$, Vescovi P. Nd: YAG and diode lasers in the surgical management of soft tissues related to orthodontic treatment. Photomed Laser Surg 2007;25:381-92.

9. Aoki A, Mizutani K, Takasaki AA, Sasaki KM, Nagai S, Schwarz F, et al. Current status of clinical laser applications in periodontal therapy. Gen Dent 2008;56:674-87.

10. Slot DE, Kranendonk AA, Paraskevas S, Van der Weijden F. The effect of a pulsed Nd: YAG laser in nonsurgical perdiodontal therapy. J Periodont 2009;80:104156.

11. Fujiyama K, Deguchi T, Murakami T, Fujii A, Kushima $\mathrm{K}$, Takano-Yamamoto T. Clinical effect of $\mathrm{CO}_{2}$ laser in reducing pain in orthodontics. Angle Orthod 2008;78:299-303.

12. Hilgers JJ, Tracey SG. Clinical uses of diode lasers in orthodontics. J Clin Orthod 2004;38:266-73.

13. Carroll L, Humphreys TR. Laser-tissue interactions. Clin Dermatol 2006;24:2-7.

14. Sulieman M. An overview of the use of lasers in general dentist practice: Laser physics and tissue interactions. (233-4). Dent Update 2005;32:228-20. 236.

15. Parker S. Laser regulation and safety in general dental practice. Br Dent J 2007;202:523-32.

16. Asencio Arana F, Garcia FV, Molina Andreu E, Vidal MJ, Martinez SF. Endoscopic enhancement of the healing of high risk colon anastomoses by low-power heliumneon laser. An experimental study. Dis Colon Rectum 1992;35:568-73.

17. Yeh S, Jain K, Andreana S. Using a diode laser to uncover dental implants in second-stage surgery. Gen Dent 2005;53:414-7.

18. Sarver DM, Yanosky M. Principles of cosmetic dentistry in orthodontics: Part 2. Soft tissue laser technology and cosmetic gingival contouring. Am J Orthod Dentofac Orthop. 2005;127:85-90.

19. Sarver DM, Yanosky M. Principles of cosmetic dentistry in orthodontics: Part 3. Laser treatments for tooth eruption and soft tissue problems. Am J Orthod Dentofac Orthop 2005;127:262-4.

20. Olivi G, Genovese MD, Caprioglio C. Evidence-based dentistry on laser paediatric dentistry. Eur J Paediatr Dent 2009;10:29-40.

21. Mezawa S, Iwata K, Naito K, Kamogawa H. The possible analgesic effect of soft-laser irradiation on heat nociceptors in the cat tongue. Arch Oral Biol 1988;33:693-4.

22. Armida MM. Laser therapy and its applications in dentistry. Pract Odontol 1989;10:9-16.

23. Peres F, Felino A, Carvalho JF. Analgesic effect of 904$\mathrm{nm}$ laser radiation (IR) in oral surgery. Rev Port Estomatol Cir Maxilofac 1985;26:205-17.

24. Neiburger EJ. The effect of low-power lasers on intraoral wound healing. NY State Dent J 1995;61:40-3.

25. Kurumada F. A study on the application of Ga-As semiconductor laser to endodontics. The effects of laser irradiation on the activation of inflammatory cells and the vital pulpotomy. Ohu Daigaku Shigakushi 1990;17:23344. 
26. Harazaki M, Isshiki Y. Soft laser irradiation effects on pain reduction in orthodontic treatment. Bull Tokyo Dent Coll 1997;38:291-5.

27. Turhani D, Scheriau M, Kapral D, Benesch T, Jonke E, Bantleon HP. Pain relief by single low-level laser irradiation in orthodontic patients undergoing fixed appliance therapy. Am J Orthod Dentofacial Orthop 2006;130:371-7.

28. Martinez-Insua A, Dominguez LS, Rivera FG, SantanaPenin UA. Differences in bonding to acid-etched or Er: YAG-laser-treated enamel and dentine surfaces. $J$ Prosthet Dent 2000;84:280-8.

29. Ceballos L, Osorio R, Toledano M, Marshall GW. Microleakage of composite restorations after acid or Er: YAG laser cavity treatment. Dent Mater 2001;17:340-6.

30. Iijima K, Shimoyama N, Shimoyama M, Yamamoto T, Shimizu T, Mizuguchi T. Effect of repeated irradiation of low-power He- Ne laser in pain relief from postherpetic neuralgia. Clin J Pain 1989;5:271-4.
31. Posten W, Wrone DA, Dover JS, Arndt KA, Silapunt S, Alam M. Low-level laser therapy for wound healing: Mechanism and efficacy. Dermatol Surg 2005;31:33440.

32. Ross G, Ross A. Low level lasers in dentistry. Gen Dent 2008;56:629-34.

33. Mah J, Hatcher D. Current status and future needs in craniofacial imaging. (179-82). Orthod Craniofac Res 2003;6(Suppl 1):10-6.

34. Quintero JC, Trosien A, Hatcher D, Kapila S. Craniofacial imaging in orthodontics: Historical perspective, current status, and future developments. Angle Orthod 1999;69:491-506.

35. Kau CH, Zhurov AI, Bibb R, Hunter L, Richmond S. The investigation of the changing facial appearance of identical twins employing a three-dimensional imaging system. Orthod Craniofac Res 2005;8:85-90. 